\title{
Espécies novas de Tetrapedia Klug (Apoidea, Anthophoridae) ${ }^{1}$
}

\section{Jesus S. Moure ${ }^{2}$}

\begin{abstract}
New species of Tetrapedia Klug (Apoidea, Anthophoridae). The following ones are considered as new species, from BRASIL: Tetrapedia albodecorata (Óbidos, Pará); T. bipartita (Ouro Preto d'Oeste, Rondônia); T. garofaloi (Cajurú, São Paulo); T. helvola (Cáceres, Mato Grosso); T. hemileuca (Tefé, Amazonas); T. hypoleuca (Santa Teresa, Espírito Santo); T. imitatrix (Ouro Preto d'Oeste, Rondônia); T. melampoda (Imperatriz, Maranhão); T. spanosticta (Itajubá, Minas Gerais); T. xanthorrhina (Vila Bela, Mato Grosso); from PARAGUAY: T. nigropilosa (Colonia Carlos Pfannel, Guayrá); and from ARgentina, T. pulchella (San Pedro Colalau, Tucumán). Some notes are added on T. alfkeni Cockerell, 1914 and on T. basalis Smith, 1879.

KEY WORDS. Hymenoptera, Apoidea, Tetrapedia, new species
\end{abstract}

Depois de ver a coleção Friese no Naturkunde Museum, Humboldt Universität, Berlim, dou a conhecer algumas das espécies que me parecem novas do Brasil, Argentina e Paraguai e notas sobre uma espécie pouco conhecida do Ecuador e outra do Amazonas. Durante estes sessenta anos de coletas tenho cerca de 1000 exemplares representativos do gênero Tetrapedia Klug, 1810.

Como utilizo alguns termos próprios nas descrições, dá-se abaixo uma explicação dos mesmos.

Denomina-se "sola" a face interna dos basitarsos posteriores dos machos, geralmente plana e de lados rebordados, às vezes armada com uma projeção dentiforme, ou profundamente modificada. "Dobra mesepisternal" no limite anterior da face lateral dos mespisternos em forte carena mais ou menos aguda, geralmente estendida até em baixo formando atrás na face lateral uma depressão mais ou menos côncava, ou a passagem para a área anterior é arredondada, sem formar depressão. Acho que essa estrutura permitirá separar as Tetrapedia em dois grandes grupos.

Ao fazer a comparação de distâncias ou intervalos entre os pontos usa-se a abreviação "dp" para significar "diâmetro de ponto"; referências ao diâmetro do ocelo, do alvéolo, do escapo e do flagelômero são indicadas apenas por "d"; "T" e "E" indicam "tergo" e "esterno"; "P+F" comprimento do pedicelo e flagelo juntos.

As medidas entre colchetes [ ] são dadas em centésimos de milímetro e agrupadas do seguinte modo: Olho e gena [comprimento:largura máxima:largura da gema de perfil]. Distâncias interorbitais [superior: máxima: inferior]. Clípeo

1) Contribuição número 1129 do Departamento de Zoologia, Universidade Federal do Paraná.

2) Departamento de Zoologia, Universidade Federal do Paraná. Caixa Postal 19020, 81531-990 Curitiba, Paraná, Brasil. Bolsista do CNPq. 
[comprimento: largura: e distância oceloclipeal, entre o bordo inferior do ocelo médio à porção transversal superior da sutura epistomal]. Distâncias dos alvéolos [interalveolar, entre os bordos internos dos alvéolos: alveolorbital, do bordo externo do alvéolo ao ponto mais próximo da órbita: alveolocelar, do bordo superior do alvéolo ao bordo inferior do ocelo lateral: $\mathrm{D}=$ diâmetro do alvéolo]. Distâncias entre os ocelos [interocelar, entre os bordos internos dos ocelos: ocelorbital, do bordo externo do ocelo ao ponto mais próximo da órbita: diâmetro do ocelo médio]. São dadas as vezes as distâncias ocelocipital, entre o bordo posterior do ocelo lateral ao bordo ocipital: orbitocipital, do bordo superior posterior da órbita ao bordo ocipital). Subantenal: comprimento da sutura entre o bordo inferior do alvéolo à anastomose com a sutura epistomal. Malar: entre o bordo inferior da órbita e o ponto mais próximo da articulação da mandíbula. Escapo: comprimento e diâmetro. Pedicelo + flagelo: comprimento do pedicelo e fagelo juntos; Flagelômeros: comprimento do primeiro, segundo e terceiro (quarto) flagelômeros e diâmetro deste último.

As referências ao comprimento de pêlos e cerdas e ao diâmetro dos pontos são feitas em $\mu$ "micra" ou micrômetros (milésimos de milímetro), entre colchetes[]. As outras referências à medidas, sem indicação, colocadas no texto entre colchetes [ ] são em centésimos de milímetro. As medidas em milímetros estão indicadas diretamente.

\section{Tetrapedia albodecorata sp.n.}

Fêmea de porte médio: comprimento total aproximado $8,08 \mathrm{~mm}$, da asa anterior 5,08 $\mathrm{mm}$; largura da cabeça $2,72 \mathrm{~mm}$ e do segundo tergo $2,74 \mathrm{~mm}$.

Preta. Flagelo por baixo pardo-ocráceo desde o terceiro flagelômero; pernas castanho-escuras com as tíbias posteriores distalmente e os metabasitarsos fracamente castanho-avermelhados. Tégulas castanho- escuras; asas hialinas; estigma e R1 amarelos, a maior parte da venação amarelo-mélea; C, Sc e M de um méleo mais escuro; hâmulos 10-9 por asa.

Pilosidade preta no vértice, mesoscuto e escutelo; fusca nas pernas anteriores e médias; preta nos dois terços basais das tíbias posteriores, passando a fulvo-amarela misturada com cerdas pardas [até $1200 \mu$ ] no terço distal e nos metabasitarsos. Quase nula em T1-4, preta em T5-6; em E1-4 as fímbrias formadas por cerdas brancas, pretas em E5-6. Branca muito curta, curto- plumosa, formando pequenos tufos brancos nos dois terços superiores das genas e principalmente no metanoto e área basal do propódeo; branca, fina, mais longa e longo- plumosa na fronte (com alguns pêlos pretos), nas paroculares, nos cantos posteriores do mesonoto, nas crestas axilares, nos lados do metanoto e nos flancos do propódeo acima do espiráculo; pêlos brancos simples na porção inferior das genas, no clípeo e supraclipeal, nos lados e parte ventral do tórax.

Pontuação fina $[25 \mu]$ esparsa [2dp] na fronte e paroculares; mais esparsa no clípeo e supraclipeal [3-4dp] com alguns pontos maiores [40 $\mu]$; com áreas anteocelares lisas descontínuas na frente dos intervalos entre os ocelos, mais fina e mais densa no vértice; nas genas com intervalos lisos [2dp]. No mesoscuto um pouco mais grossa [30-35 $]$, mais esparsa [2-4dp], mais adensada ao longo da linha média 
[1dp] formando duas séries bastante regulares a cada lado, com alguns micro-pontos intercalados, nos lados e nos cantos posteriores mais densa; no escutelo igual à dos lados do mesoscuto; no metanoto um pouco mais fina e os intervalos lisos [2dp]; na depressão mesepisternal mais fina, os pontos muito separados por intervalos lisos [4-6dp] na parte inferior, um pouco menores em cima, abaixo e atrás mais brilhantes; os metepisternos lisos abaixo do espiráculo. Propódeo inteiramente micro-reticulado com os pontos de implantação dos tufos brancos mais numerosos para a base da área basal [2-3dp], esta confinada por um largo $\mathrm{V}$ sem pontos e abaixo novamente com pontos e tufos brancos; os pontos maiores nos flancos e acima dos espiráculos com pêlos plumosos brancos mais longos. Em T1-4 (com os bordos um pouco sinuados) bastante esparsa, um pouco mais densa na base de T1 [2-4dp], toda a superfície delicadamente transverso-canaliculada passando a lisa junto as margens, principalmente em T4; em T5-6 mais desenvolvida, com as cerdas começando já nos lados de T4.

Cabeça relativamente curta com olhos engrossados, seu comprimento menos de duas vezes sua largura; genas de perfil menos da metade do olho [182:100:40]; face relativamente estreita, órbitas quase retas, convergentes para baixo e a interorbital máxima pouco menos de 3/4 do comprimento do olho [132:135:115]; malar linear [2]; clípeo pouco deprimido na sutura epistomal transversal, tão longo como $3 / 5$ da sua largura e metade da sua distância ao ocelo [62:100:120], apicalmente com uma série de pontos limitando a barra lisa marginal evidente apenas no terço médio e parecendo uma fenda em vista inferior; subantenal tão longa como $2 \mathrm{~d}$ alvéolo; supraclipeal pouco abaulada; interalveolar $2 \mathrm{~d}$, alveolorbital $1 \mathrm{~d}$ de alvéolo [40:20:70:d20]; sulco frontal quase nulo na supraclipeal aparecendo em fina depressão antes do ocelo médio; subantenal [40]; interocelar apenas $1,28 \mathrm{~d}$ e a ocelorbital apenas 1,1d de ocelo [32:28:d25]. Labro tão longo como 5/8 da sua largura, com uma fímbria basal bastante notável, relativamente plano e com poucos pontos rasos. Escapo curto [55:d20], claviforme [P+F 210], mais curto que os três primeiros flagelômeros; o flagelômero basal mais longo que duas vezes o segundo (este mais curto que seu diâmetro), terceiro e quarto subiguais, mais longos que seu diâmetro [32:14:20: 20:d17]. Dobra mesepisternal em forte carena aguda estendida até em baixo formando atrás uma depressão bastante côncava. Fêmures posteriores pouco inchados [170:60], as tíbias tão grossas e mais longas que os fêmures [200:60], os metabasitarsos mais curtos que a tíbia.

Holótipo fêmea. Brasil, Pará: Óbidos, 21-VI-1902, A. Ducke leg., na Coleção Pe. J.S. Moure, Departamento de Zoologia, Universidade Federal do Paraná (DZUP).

No exemplar tipo foi necessário substituir o alfinete partido em três e perderam-se a asa anterior esquerda e o flagelo da antena direita.

Espécie facilmente reconhecível pelas asas hialinas, estigma e R1 amarelos; pelos olhos grandes com as órbitas internas quase retas e principalmente pela pilosidade branca formando pequenos tufos ou flocos curtos muito destacados nas genas, tórax e propódeo, valendo-lhe o nome específico.

Parte dos exemplares quebrados da coleção Ducke foram doados pelo Dr. W. Egler, Diretor do Museu Goeldi, para a coleção de abelhas da Universidade 
Federal do Paraná (DZUP) quando lá estive com o Prof. Charles D. Michener em 1955 para estudo dos tipos de Ducke. Essa coleção ficou por muitos anos quase sem curadoria e muitos alfinetes se quebraram no corpo da abelha (verdete), nos pontos de fixação das etiquetas, ou no ponto de contato com o fundo da gaveta. $\mathrm{O}$ clima úmido e a falta de curadoria por 40 anos no clima de Belém quase destruiram essa coleção.

Nessa viagem com o Prof. Michener, foram salvos muitos tipos que foram designados como tais na coleção do Museu Goeldi e relacionados posteriormente NASCIMENTO (1979). Alguns cótipos e vários exemplares sem classificar foram trazidos para Curitiba onde se tem feito o possível para preservá-los como preciosa lembrança do grande estudioso das abelhas da Amazônia e do Nordeste, Adolfo Ducke.

Vi também alguns "tipos" de Ducke no Museu de Zoologia, Universidade de São Paulo, São Paulo. Outros foram doados como "tipos" aos Museus de Londres, de Paris, com a vinda da coleção Vachal, e no Naturkunde Museum da Universidade de Humboldt com a adquisição da coleção Friese.

\section{Tetrapedia bipartita sp.n.}

Fêmea de grande porte: comprimento total aproximado $11,67 \mathrm{~mm}$, da asa anterior 10,0 mm; largura da cabeça 3,26 mm e do segundo tergo $3,35 \mathrm{~mm}$.

Preta, sem desenhos amarelos. Flagelo ligeiramente pardacento; fêmures castanhos; tíbias posteriores pardo-avermelhadas. Tégulas castanho-escuras; asas com a metade basal escura, a apical amarelento-leitosa; a venação basal preta, o estigma e venação distal amarelentos; hâmulos 13 por asa.

Pilosidade predominante preta. Branca na porção inferior das paroculares, nos cantos inferiores do clípeo e alguns pêlos longo-plumosos na parte inferior da fronte e acompanhando o bordo superior da área supraclipeal e parte proximal das genas; formando um pequeno tufo na extremidade posterior das tíbias do último par. Franja marginal de E1, terço médio da franja de E2 e alguns pêlos no meio da franja de E3, brancos.

Pontuação fina $[20 \mu]$ e esparsa na fronte, os intervalos lisos e brilhantes [2-3dp]; igual nas paroculares superiores, nas paroculares inferiores adensando-se um pouco junto as órbitas; no clípeo esparsa [2dp], com alguns pontos maiores e micro-pontos muito esparsos intercalados, os intervalos um pouco mais lisos ao longo do meio; no disco da supraclipeal muito esparsa com alguns pontos grossos $[40 \mu]$ e micropontos esparsos intercalados; densa no vértice, porém com uma área lisa a cada lado, entre os ocelos e as órbitas; bastante fina e esparsa na porção anterior das genas. No mesoscuto mais grossa e mais funda que na fronte, densa, os intervalos lisos iguais aos pontos, deixando duas áreas mais lisas entre o sulco médio e as parápsides, esses intervalos lisos cerca de 2-3dp com alguns micropontos intercalados muito esparsos; no escutelo mais densa com uma linha média vaga menos pontuada e no bordo metanotal uma faixa estreita mais brilhante; no metanoto bastante densa; nos mesepisternos mais fina e mais esparsa que no mesoscuto e atrás da dobra mesepisternal ainda mais esparsa, um pouco adensada para cima na região 
subalar; nos metepisternos densa acima do espiráculo, abaixo sem pontos, microreticulada. Propódeo com a área basal mate, micro-tesselada e alguns pontos grossos esparsos [2-3dp] na porção superior; nos flancos mais densa e os intervalos microreticulados. Em T1-3 com poucos pontos marcando o limite superior das depressões marginais e a superfície brilhante porém micro-transverso-canaliculada; em T4-6 a pontuação pilígera muito desenvolvida.

Olhos 1,8 mais longos que largos, mais largos que as genas [225:120:82]; malar linear [3]; face estreitada para baixo, a interorbital máxima menor que o comprimento do olho [170:192:142]; clípeo pouco abaulado, 1,57 mais largo que longo e seu comprimento mais de $2 / 3$ da sua distância ao ocelo [88:138:135], depressão apical fraca, visível em certa luz, separada por pontos, os cantos inferiores ligeiramente deprimido-rebordados; área subantenal pouco mais longa que o diâmetro do alvéolo [30]; distância interalveolar duas vezes a alveolorbital, esta pouco maior que o alvéolo [60:30:80:d25]; sulco frontal aparecendo apenas junto ao ocelo médio e este destacado por um sulco estreito anterior; distância interocelar quase igual à ocelorbital, porém menor que dois diâmetros de ocelo [42:40:d27]. Labro densamente pontuado e pouco deprimido ao longo do meio. Escapo subcilíndrico, três vezes seu diâmetro [65:d22] e mais curto que a ditância alveolocelar [P+F 290], mais longo que os dois primeiros flagelômeros juntos; flagelômero basal quase duas vezes o segundo, este mais curto que seu diâmetro, o terceiro mais longo [38:20:26:d24]. Dobra mesepisternal grosso-careniforme no terço superior e esvaindo-se aos poucos.

Holótipo fêmea. BRASIL, Rondônia: Ouro Preto do Oeste, 20-VIII- 1987, Claudionor Elias leg.. Um parátipo do mesmo local e coletor, 12-VIII-1987. Ambos exemplares obtidos durante a execução do Projeto "Polo Noroeste" e depositados na Coleção Pe. J.S. Moure (DZUP).

Distingue-se facilamente de outras Tetrapedia pelo colorido bipartido das asas, preto-iodino na metade basal e amarelo-leitoso na metade apical, lembrando T. basalis Smith, 1879. Nesta o tamanho é quase igual, porém separa-se facilmente pela pilosidade fulvo-pálida que reveste quase toda tíbia posterior e os metabasitarsos e pela falta de pontos na área basal do propódeo. Veja-se no final a descrição de um exemplar de Tefé, AM, comparado com o tipo.

\section{Tetrapedia garofaloi sp.n.}

Macho de porte relativamente grande: comprimento total aproximado $10,00 \mathrm{~mm}$, da asa anterior $8,15 \mathrm{~mm}$; largura da cabeça $3,12 \mathrm{~mm}$, do segundo tergo $2,60 \mathrm{~mm}$.

Preta, no clípeo com faixa amarela premarginal completa, um pouco arqueada e o bordo superior levemente emarginado; na base das mandíbulas uma grande mancha amarela. Flagelo pardo-claro inferiormente; extremidade distal das tíbias posteriores e metabasitarsos amarelo- ocráceo-pálidos; margens dos tergos um pouco desbotadas. Tégulas pretas brilhantes; asas mais escurecidas nas células radial, média e cubitais, a porção distal livre quase hialina; estigma e venação pardo-escuros, apenas o R1 um pouco mais claro; hâmulos 10 por asa. 
Pilosidade cerdosa preta na fronte, vértice, mandíbulas, mesoscuto, escutelo e metanoto, área basal e flancos do propódeo e em todo lado dorsal do abdômen. Branca formando um tufo na base da fronte e nas paroculares inferiores, as cerdas do clípeo, da supraclipeal, labro e parte inferior das genas; bastante longa em todo lado ventral do tórax até meia altura dos episternos, todo lado ventral do abdômen e formando pequeno tufo na extremidade distal das tíbias anteriores e médias e ocupando os 2/7 distais nas posteriores. Uma mancha alongada castanho-ocrácea na metade distal da face externa anterior das tíbias médias. A franja dos metabasitarsos escura, as cerdas um pouco ocráceo-pardas na base, mais palidas aos lados da sola, bastante larga na base $[900 \mu]$, no meio $[900 \mu]$ e subapicalmente $[1200 \mu]$, depois encurtada rapidamente; as cerdas ocráceas da face interna longas [até $600 \mu$ ]. Em T1 bastante longa e numerosa; em T2-4 fina e curta e apenas ao longo do meio e os lados glabros, com algumas cerdas no bordo extremo de T3-4; em T5 em tufo um pouco afastado da base com pêlos finos plumosos de um cinza escuro apicalmente com cerdas pretas salientes [até $500 \mu$ ]; em T6-7 inteiramente pretas e cobrindo o bordo apical. Em E3 com uma área em arco coberta por pilosidade branca denso-plumosa, as cerdas marginais de E3-4 cremosas, longas, voltadas para dentro; em E5 com pouca pilosidade e em E6 preta. Os tufos do escutelo pouco evidentes com as cerdas mais longas até $800 \mu$ e no vértice até $700 \mu$.

Pontuação toda pilígera e os intervalos lisos, porém na área basal do propódeo reticulados. Fina e moderadamente densa na fronte com a porção anteocelar contínua quase inteiramente lisa até pouco antes das órbitas; nas paroculares um pouco mais esparsa. No clípeo esparsa aos lados de uma carena média lisa, relativamente fraca; na supraclipeal o disco largamente liso, apenas com alguns pontos aos lados; no vértice densa e fina em direção às orbitas; nas genas moderadamente densa em cima, mais esparsa em baixo. No mesoscuto moderadamente grossa $(40 \mu)$; na linha média, um pouco deprimida, disposta em três a quatro séries irregulares a cada lado, os intervalos estreitos (menos de $1 \mathrm{dp}$ ), seguidas de uma grande área longitudinal menos pontuada [largura até $20 \mu$ ] com alguns micropontos esparsos e para os lados junto às parápsides mais grossa [50-60 $\mu$ ], os intervalos lisos (variando entre $1 / 2-1 \mathrm{dp}$ ), nos bordos anterior, laterais e posterior mais fina e mais densa; no escutelo [40 $\mu$, bastante densa, deixando estreita linha média lisa anterior, os intervalos lisos menores que os pontos, a faixa lisa premetanotal evidente (largura $2 \mathrm{dp}$ ) em toda a extensão; no metanoto mais fina e mais densa no meio, esparsa nos lados e os intervalos lisos maiores que os pontos; na face anterior dos mesepisternos fina e densa, na face lateral deprimida os pontos enormes [ $100 \mu]$, em parte seriados para baixo irregularmente, os intervalos reticulados (desde um pouco maiores até $1 / 2 \mathrm{dp}$ ), a distribuição um pouco irregular; nos metepisternos fina e densa em cima, nula em baixo com a superfície reticulada. Propódeo na área basal com limites pouco definidos, os pontos quase como no escutelo, irregularmente dispostos, os intervalos variáveis [1-3dp] inteiramente reticulados, sem linha média lisa, substituida apenas por um sulco médio obsoleto; nos flancos densa e grossa [50 $\mu$ ), os intervalos menores que os pontos, reticulados. Em T1 com bastante pilosidade longa [160 $\mu]$ sem invadir a depressão marginal; em T2-4 confinada ao terço discal e invadindo a base das depressões marginais; em T4-6 mais densa, coberta pela pilosidade. 
Olho 2,23 mais longo que largo, cerca do dobro da gena [205:92:50]; face convergente para baixo com a interorbital máxima menor que o comprimento do olho [170:195:130]; clípeo 1,56 mais largo que longo, seu comprimento pouco mais que a metade da sua distância ao ocelo médio [80:125:175], abaulado, praticamente sem depressão apical porém com os cantos inferiores deprimidos e fracamente rebordados; supraclipeal pouco abaulada com a subantenal pouco mais longa que $o$ diâmetro do alvéolo [30]. Malar linear [3]; interalveolar mais de dois diâmetros do alvéolo, 1,57 vezes a alveolorbital [56:35:70:d24]; sulco frontal representado por um ponto alongado, atenuado para cima, no alto da supraclipeal e reaparecendo na área lisa anteocelar; interocelar um pouco maior que a ocelorbital, cerca de 1,57 o ocelo médio [44:42:d28]. Labro pouco mais longo que a metade da sua largura [50:95], pouco pontuado, levemente deprimido ao longo do méio e o bordo anterior subtruncado com os cantos arredondados e com ligeira sinuosidade média. Escapo três vezes seu diâmetro [65:22], mais longo que os dois primeiros flagelômeros juntos, menos de $1 / 4$ do pedicelo e flagelo juntos [P+F 290]; flagelômero basal menos de duas vezes o segundo, este menor que o terceiro, terceiro e quarto subiguais superando em muito seu diâmetro [32:18:24:24:d20]. Dobra mesepisternal fina seguida de depressão grosso-pontuada. Coxas e trocanteres posteriores inermes; fêmures com pilosidade branca bastante longa, 2,5 sua largura [200:80]; tíbias posteriores tão grossas como os fêmures porém mais longas [260:80]; metabasitarsos pouco curvos, de lados quase subparalelos, arco um pouco mais estreitos na base [200/50:60:60], a sola inerme em espátula estreita fracamente curva e apicalmente parabolóide.

Fêmea de porte grande: comprimento total aproximado $10,0 \mathrm{~mm}$, da asa anterior $8,75 \mathrm{~mm}$; largura da cabeça $3,20 \mathrm{~mm}$ e do segundo tergo $2,20 \mathrm{~mm}$.

Preta, com faixa premarginal amarela no clípeo e uma grande mancha na base das mandíbulas. Flagelo por baixo avermelhado. Fêmures castanhos; terço distal das tíbias posteriores e metabasitarsos avermelhados. Bordo marginal desbotado em T1-4. Tégulas pretas, brilhantes mais escurecidas na base e quase hialinas na parte livre apical; estigma e venação escuros, R1 um pouco ocráceo. Pilosidade cerdosa predominante preta. Branca em baixo na fronte, formando um tufo por baixo dos alvéolos e cobrindo quase toda a parocular inferior, na metade inferior das genas; os pêlos no clípeo e na supraclipeal; no labro um pouco pardacentos e nas mandíbulas pretos; uma série de cerdas pretas acompanhando a órbita interna. Branca em todo lado inferior do tórax até meia altura nos episternos, nas coxas, trocanteres e fêmures e fímbrias de E1-3 e na base do quarto, neste apicalmente e nos dois últimos inteiramente preta. Tufos esbraquiçados pequenos na extremidade distal das tíbias dos dois primeiros pares e uma estria vaga de pêlos pardo-ocráceos no terço distal da face externa anterior das tíbias médias; as cerdas em parte brancas e em parte pretas nas tíbias posteriores e terminando no terço distal num tufo de cerdas amarelofulvas e pêlos finos plumosos [as cerdas salientes até $1600 \mu$ ]; nos metabasitarsos as cerdas longas $[1600 \mu]$ pretas atrás, pardo-ocráceas na frente e a pilosidade fina denso-plumosa posterior um pouco para o cinza- escuro. No propódeo com pelinhos micro-plumosos formado pequenos tufos grossos pardo-ocráceos em cada ponto da área basal e também na parte média do metanoto. T1-4 quase glabros com pequenos pêlos ou cerdas muito esparsos na parte basal, as depressões marginais glabras, a de 
T1 fracamente micro-transverso-canaliculada; desenvolvida nos lados de T4 e principalmente nos seguintes, ainda que um pouco mais esparsa na base de T5 com cerdas curto-plumosas parecendo mais grossas nos dois últimos.

Pontuação na fronte relativamente fina $[15-20 \mu)$, moderadamente esparsa nas paroculares; nas áreas lisas preocelares com alguns micro-pontos cerdosos não deixando as áreas inteiramente lisas; no vértice muito fina e densa. No mesoscuto o sulco médio mais forte e mais deprimido que no macho e a pontuação com distribuição parecida porém os pontos de um modo geral mais finos (no mesoscuto até $30 \mu$ e nos mesepisternos até $70 \mu$ ). No escutelo a linha média e principalmente a pré-metanotal lisas e brilhantes, muito evidentes; no metanoto mais fina e mais densa, no meio com alguns pontos menores mais densos. Propódeo todo micro-reticulado; área basal com pontos ornados com micro-tufos confinados ao quarto basal, com o sulco médio mais evidente, limitada por um arco muito aberto reticulado, em baixo esparsa, nos lados muito densa antes da dobra para os flancos; nos flancos antes do espiráculo densa, para baixo mais esparsa. Nos tergos apenas com pontos cerdígeros e o primeiro com a superfície delicadamente transverso-canaliculada, mais visível em certa luz.

Olho 2,2 mais longo que largo, 1,25 mais largo que a gena; a interorbital máxima cerca 4/5 do comprimento do olho; clípeo 1,7 mais largo que longo, seu comprimento $3 / 5$ da distância ao ocelo, moderada mente abaulado, muito vagamente sulcado ao longo do meio, a depressão apical fracamente indicada, apenas no quarto médio limitada por pontos; subantenal 1,9 mais longa que o diâmetro alveolar; interalveolar duas vezes a alveolorbital e esta pouco mais de um diâmetro de alvéolo; supraclipeal pouco abaulada; início do sulco frontal formado por três pontos alongados no alto da supraclipeal, mais forte como sulco antes do ocelo médio e abraçando sua metade anterior; interocelar um pouco maior que a ocelorbital e duas vezes o diâmetro transversal do ocelo médio. Labro tão longo como $3 / 4$ da sua largura basal, moderadamente pontuado e deprimido ao longo do meio, truncado apicalmente com os cantos arredondados. Escapo 3,25 seu diâmetro, cerca de 2/9 do com primento do flagelo e pedicelo juntos; flagelômero basal duas vezes mais longo que o segundo, este mais curto que o terceiro igual ao seu diâmetro, o quarto um pouco mais longo que seu diâmetro. Dobra mesepisternal anterior forte, careniforme, e na depressão com pontos grossos até $100 \mu$. Hâmulos 10 por asa.

Holótipo macho. BRASIL, São Paulo: Cajurú (Fazenda Santa Carlota), e mais um parátipo macho, emergidos dos ninhos artificiais em 13-VIII-1988 e quatro fêmeas em 11, 17, 21 e 26-IX-1988, na Coleção Pe. J.S. Moure (DZUP). Outros exemplares de ninhos estudados por C.A. Garófalo e Camilo e Serrano em 1988, encontram-se no Departamento de Ciências Biológicas da Faculdade de Filosofia Ciências e Letras, Universidade de São Paulo, Campus de Ribeirão Preto e são considerados como parátipos.

\section{Tetrapedia helvola sp.n.}

Fêmea de tamanho médio: comprimento total aproximado $7,91 \mathrm{~mm}$, da asa anterior 7,42 $\mathrm{mm}$; largura da cabeça 2,80 e do segundo tergo $2,6 \mathrm{~mm}$.

Preta, sem desenhos amarelos. Antenas ferrugíneas; fêmures posteriores castanho-escuros, tíbias do mesmo par castanho-avermelhadas. Tégulas de um 
castanho muito escuro, quase pretas; asas lavadas de um amarelo-pardo muito pálido, célula radial levemente ocráceo-amarelada; estigma amarelo, venação mélea, porém M e R1 amareladas; hâmulos 11 por asa.

Pilosidade cerdosa quase toda preta. Esbranquiçada abaixo dos alvéolos e um grande tufo de cerdas longo-plumosas pálidas na porção inferior da fronte com uma ou outra cerda preta misturada; branca no labro, mandíbulas e genas passando a pretas no hipóstoma. Pêlos cremosos curto-plumosos, bastante densos no pronoto e contornando os lobos por trás, formando linhas na parte posterior do sulco médio do mesoscuto e atrás das parápsides ligadas entre si pela linha transcutal (ou escuto-escutelar) entre o mesoscuto e o escutelo, cobrindo uma pequena área semicircular na base do mesmo e formando tufo atrás das axilas prolongado até a base das asas pela cresta axilar; cerdas brancas longas no bordo anterior das tíbias posteriores, amarelas na extremidade distal posterior e no bordo anterior dos metabasitarsos. Em T1-4 muito reduzida, fina e esparsa na base, mais evidente nas extremidades laterais de T3 e ainda mais em T4 deixando as depressões marginais inteiramente glabras; muito desenvolvida em T5-6; as fímbrias dos esternos inteiramente pretas.

Pontuação na fronte moderadamente grossa $[30 \mu]$ e pouco densa, os intervalos lisos [1dp] mesmo nas paroculares superiores, um pouco mais esparsa nas inferiores; mais forte e mais esparsa no clípeo [2-4dp] com fraca indicação da linha média lisa; na supraclipeal muito mais esparsa, quase nula no disco; nas genas mais fina e mais esparsa que na fronte; no vértice densa e fina com pequena área lisa antero-lateral aos ocelos laterais e outra maior diante do ocelo médio, ligeiramente côncava. No mesoscuto forte e densa [1-1,5dp], mais adensada ao longo do súlco médio e atrás sem deixar área lisa diferenciada entre o sulco e as parápsides; no escutelo densa, os intervalos menores que os pontos, com vestígios de linha média anteriormente; no metanoto um pouco mais forte e fina e os intervalos lisos [1dp]; nos mesepisternos na depressão atrás da dobra anterior esparsa, na metade inferior quase nula e na subalar mais densa, para trás esparsa e os intervalos micro-reticulados.

Nos tergos a pilosidade como nas fêmeas, porém os micropontos pilígeros (pelinhos finos curtos) um pouco mais esparsos não só em T1 mas também nos dois seguintes; em T4 mais desenvolvida formando tufo marginal denso- plumoso; essa franja denso-plumosa, pardo-cremosa ainda mais notável em T5-6; T7 menos piloso e com o bordo posterior emarginado. Em E1-2 a pilosidade preta, em E3 denso-plumosa, cremosa no disco e com longas cerdas marginais voltadas para dentro, cremosas na base e distalmente escurecidas; em E4 também com essas cerdas um pouco menos longas; E5 glabro; E6 bilobado e com as cerdas típicas deste gênero formando uma série esparsa transversal, no meio dirigidas para trás e continuadas por 5-7 cerdas mais grossas como que coladas entre si e um pouco curvadas para dentro sem chegar ao bordo apical. As margens de T1-4 desbotadas e um pouco sinuadas.

Holótipo fêmea. Brasil, Mato Grosso: Cáceres, 5-IV-1986, e como os parátipos todos os machos e fêmeas coletados entre 28-XI-1984 e 6-IV-1986 por Claudionor Elias nessa mesma localidade, durante o projeto "Polo Noroeste", na Coleção Pe. J.S. Moure (DZUP). 
Principais variações entre os parátipos: em alguns exemplares há uma separação maior entre os pontos do mesoscuto que ficam entre o sulco médio e as parápsides, os intervalos um pouco maiores que $1 \mathrm{dp}$, mas mesmo nos casos extremos sem formar área lisa destacada a cada lado no disco. Há também alguma variação na densidade dos pontos na área basal do propódeo ficando a linha média lisa mais ou menos obliterada e o reticulado muito superficial, porém nunca inteiramente lisos e polidos. No metanoto de alguns espécimens a pontuação é mais escassa aos lados. Em alguns machos a dilatação basal da sola tende mais para angulosa formando saliência no mesmo plano da sola e não perpendicular ao bordo como em $T$. diversipes.

\section{Tetrapedia hemileuca sp.n.}

Fêmea de porte grande: comprimento total aproximado $11,67 \mathrm{~mm}$, da asa anterior $10,0 \mathrm{~mm}$; largura da cabeça $3,28 \mathrm{~mm}$ e do segundo tergo abdominal 3,35 $\mathrm{mm}$.

Preta, com minúsculas manchas amarelas na base das mandíbulas e reduzidas nas extremidades laterais do clípeo e muito vaga na metade apical do labro. Flagelo ligeiramente pardo-ferrugíneo; fêmures castanho-escuros; tíbias posteriores e metabasitarsos ferrugíneos. Tergos com a margem desbotada. Tégulas pardo-castanhas na parte lisa; asas com a metade basal escurecida, e a distal amarelo-leitosa; venação basal escura, estigma e venação apical amarelo-méleos. Hâmulos 13 por asa.

Pilosidade predominante preta. Branca junto aos alvéolos, nas paroculares inferiores e nas genas; os poucos pêlos do clípeo, labro e mandíbulas pálidos; cremosa na face inferior do tórax. Denso curto-plumosa, um pouco parda, no escutelo e metanoto. Nas tíbias posteriores e metabasitarsos amarela exceto alguns poucos pêlos pretos junto à placa basitibial. Franjas marginais dos esternos inteiramente pretas.

Pontuação muito parecida com a da espécie anterior, porém mais fina e mais esparsa na fronte [3-4dp]; no clípeo um pouco mais grossa que na fronte, muito esparsa no disco; na supraclipeal deixando quase toda a área discal lisa e com quatro a cinco pontos marcando a cada lado o declive para os alvéolos com pontuação mais densa em volta; com grande área lisa entre os ocelos e as órbitas, para trás muito fina e densa, entre os ocelos um pouco mais grossa. No mesoscuto os pontos mais finos $[25 \mu]$ que na espécie anterior, adensados junto ao sulco médio, os intervalos lisos [3dp], mais densa para trás; no escutelo muito mais densa, intervalos com 1dp ou menos e sem vestígios da linha média; no metanoto densa; nos mesepisternos os intervalos lisos grandes [mais de 4dp], adensada na área subalar; nos metepisternos densa na metade superior, nula abaixo do espiráculo, a superfície mate, micro-tesselada. No propódeo toda área mate, micro-reticulada, com pontos fracos superficiais; nos flancos densa, pilígera. Em T1-3 quase nula, com pontinhos esparsos delimitando as depressões marginais, a superfície micro-canaliculada transversalmente, o canaliculado mais evidente nas depressões marginais; os pontos pilígeros mais densos e mais fortes em T4 deixando a linha média sem pontos; em T5-6 bastante mais densa. 
Olhos pouco mais longos que duas vezes sua largura, e 1,6 vezes mais largos que as genas [227:100:60], estas um pouco deprimidas na metade proximal às órbitas; face mais estreitada para baixo, a interorbital máxima menor que o comprimento do olho [180:190:140]; clípeo abaulado com uma carena longitudinal vestigial na metade basal, 1,3 vezes mais largo que longo e seu comprimento cerca de 3/4 da distância ao ocelo médio [92:120:140]; subantenal 1,5 o diâmetro do alvéolo [45]; malar linear [3]; supraclipeal pouco abaulada; interalveolar quase o dobro da alveolorbital ou quase três vezes o diâmetro do alvéolo [60:36:80:d22]; o sulco frontal representado por dois pontos mais grossos alongados longitudinalmente e depois uma fina linha deprimida antes do ocelo; a distância interoceolar pouco maior que a ocelorbital e ligeiramente maior que 1,5 o ocelo médio [46:43:d30]. Labro tão longo como $3 / 5$ da sua largura, o bordo anterior em arco um pouco truncado e fracamente deprimido ao longo do meio. Escapo subcilíndrico, três vezes seu diâmetro [66:d22], bastante mais curto que a distância alveolocelar e um pouco mais longo que os dois primeiros flagelômeros juntos [P+F 290]; flagelômero basal duas vezes o seguinte, o terceiro um pouco mais longo, igualando seu diâmetro [42:20:24:d24]. Sulco médio do mesoscuto pouco marcado; dobra mesepisternal um pouco grossa em cima, realçada atrás pela área deprimida.

Holótipo fêmea. BRASIL, Amazonas: Tefé, 1-4-XI-1961, na coleção Pe. J.S. Moure (DZUP).

Lembra pelo colorido das asas Trigona dimidiata Smith, 1854 e assemelhase à espécie T. bipartita de Ouro Preto do Oeste, Rondônia. Separa-se à primeira vista pela pilosidade amarela das pernas posteriores. Lembra também Tetrapedia amplitarsis Friese, 1899, pelo seu porte e colorido da pilosidade das pernas posteriores. T. amplitarsis difere pela cor das asas inteiramente fuscas, sulco do mesoscuto obsoleto, não deprimido e desaparecendo na metade posterior, pontuação do mesoscuto mais esparsa e a área basal do propódeo apenas mate-reticulada, absolutamente sem pontos e as franjas dos esternos segundo ao quarto pálidas. $\mathrm{O}$ sulco é completo em $T$. hemileuca, porém não deprimido nem fortemente pontuado aos lados como na maior parte das Tetrapedia.

Pelos vestígios de desenhos amarelos é possível que pertença ao grupo de espécies com faixa amarela premarginal no clípeo e manchas na base das mandíbulas. assemelha.

No final do trabalho faço uma comparação com $T$. basalis Smith a que se

\section{Tetrapedia hypoleuca sp.n.}

Fêmea de porte grande: comprimento total aproximado $11,0 \mathrm{~mm}$, da asa anterior $9,5 \mathrm{~mm}$; largura da cabeça $3,4 \mathrm{~mm}$ e do segundo tergo abdominal $3,3 \mathrm{~mm}$.

Preta, sem desenhos amarelos. Flagelo por baixo castanho-ferrugíneo; fêmures castanhos; tíbias posteriores com o terço distal e os metabasitarsos amarelo-ferrugíneos. Tégulas castanho-escuras a pretas; asas fuscas; estigma e venação cinzaescuros, quase pretos; hâmulos 12 por asa.

Pilosidade predominante preta. Branca, um pouco amarelada, no lado ventral do tórax, coxas e trocanteres médios e posteriores e fimbrias dos quatro primeiros 
esternos; essa pilosidade ventral relativamente longa e grossa. Preta, longa e densa nas coxas anteriores. Branca na parte inferior da fronte, labro, clípeo, supraclipeal (uma ou outra cerda preta intercalada), paroculares e genas, nestas os pelinhos penugentos na porção superior. No escutelo formando dois tufos imperfeitos e a maior parte das cerdas do mesoscuto e escutelo relativamente curta [as maiores no escutelo até $900 \mu$ ]. Preta nas pernas, porém amarela nos três oitavos das tíbias posteriores e atrás nos metabasitarsos, misturada com pêlos finos plumosos mais curtos intercalados, igualmente amarelos. Na base de T1-2 muito curta, fina e densa; em T3-4 mais longa e esparsa no disco; nula nas depressões marginais de T1-4; em T5-6 aos lados da placa pigidial bastante longa, denso-plumosa; em E5-6 preta.

Pontuação moderada [25-30 $\mu$ ] e esparsa com intervalos lisos [1-2dp] na fronte, com linha lisa substituindo o sulco frontal; as ante-ocelares lisas independentes entre si; densa nas paroculares; no clípeo ligeiramente mais grossa e muito esparsa, os intervalos muito grandes no disco, o sulco premarginal com os pontos soldados entre si no terço médio; no disco da supraclipeal muito esparsa e em cima com vestígios do início do sulco frontal; densa no vértice; mais fina nas genas, os intervalos micro-reticulados (2-4dp). No mesoscuto densa ao longo do meio, junto aos bordos laterais e cantos posteriores, no disco uma área mais lisa (3-4dp) a cada lado, com alguns micro-pontos intercalados; no escutelo densa deixando fina linha média transverso-canaliculada e atrás a faixa lisa pouco definida; no metanoto mais fina, os intervalos vagamente reticulados (1-2dp); na depressão lateral dos mesepisternos densa em cima, no disco fina e esparsa (2-3dp) quase nula para baixo, porém forte e esparsa abaixo da depressão e para trás; nos metepisternos densa acima do espiráculo e nula abaixo. Na área basal do propódeo densa a cada lado de uma linha média, os intervalos fortemente reticulados nos flancos anteriores ao espiráculo, sem pontos porém fortemente reticulada limitando a área basal com alguns pontos abaixo e em direção ao espiráculo. Tergos com a superfície transverso-micro-canaliculada, em T1-2 para a base finíssima e muito densa, em T3-4 mais esparsa deixando a parte média lisa; depressões marginais sem pontos até T4; nos lados de T4 e em T5-6 bastante densa, cerdígera.

Olho 2,1 sua largura; genas entre $2 / 3$ e 3/8 da largura do olho [230:1 10:40]; malar linear [4]; interorbital máxima 9/10 do comprimento do olho [190:210:160]; porção transversal da sutura epistomal bastante deprimida; clípeo quase duas vezes mais largo que longo, seu comprimento 4/7 da distância clipeocelar [80:152:140], depressão apical estreita, muito forte, os pontos limitantes unidos em sulco contínuo no terço médio; sutura subantenal 1,5d alveolar [40]; interalveolar 1,6 da alveolorbital, esta 1,5d alveolar [65:40:90;d27]; sulco frontal interrompido na fronte reaparecendo como fina depressão na área ante-ocelar média. Labro 1,6 mais largo que longo, quase plano, truncado apicalmente com os cantos arredondados. Escapo 3,4 vezes seu diâmetro [75:d22], 1/4 do flagelo e pedicelo juntos [P+F 300]; flagelômero basal o dobro do segundo, o terceiro e quarto progressivamente mais longos mas sem superar o próprio diâmetro [40:20:22:24:d25]. Mesepisterno com forte dobra anterior, finamente carenada, completa até em baixo.

Holótipo fêmea. BRASIL, Espirito Santo: Santa Teresa (alt. 656m), com vários parátipos topotípicos, 16-22-XI-1966 e 2-8-I-1968, C. \& C.T. Elias leg. . Vários parátipos de Conceição da Barra (alt. 3m), Espírito Santo, 19-25-XI-1968, 
C. \& C.T. Elias leg., na Coleção Pe. J.S. Moure (DZUP). Os exemplares da localidade mais alta são mais robustos que os do litoral.

Espécie grande, notável pela grossa pilosidade branco-amarelenta do lado ventral do tórax, incluindo as coxas e trocanteres, menos as coxas anteriores, densamente cobertas de pilosidade preta; a pilosidade branca continua nos quatro primeiros esternos, nos dois últimos preta. Esta caraterística valeu-lhe o nome específico.

Pertence ao grupo de espécies com dobra mesepisternal forte, elevada em carena fina e aguda, completa até em baixo, determinando uma depressão posterior com pontuação fina a moderada bastante esparsa no disco e mais densa para cima. O fino canaliculado transversal dos tergos bastante evidente em certa luz, e tambem a densa pontuação muito fina na base do primeiro tergo e um pouco menos densa no segundo.

\section{Tetrapedia imitatrix sp.n.}

Fêmea de porte robusto: comprimento total aproximado $10,0 \mathrm{~mm}$, da asa anterior $9,15 \mathrm{~mm}$; largura da cabeça $3,35 \mathrm{~mm}$ e do segundo tergo abdominal 3,20 $\mathrm{mm}$.

Preta, sem desenhos amarelos. Flagelo inferiormente ferrugíneo; desta mesma cor o terço distal das tíbias posteriores e metabasitarsos. Tergos com a margem desbotada. Tégulas pretas; asas fuscas; venação basal escura, estigma $\mathrm{e} R 1$ um pouco amarelados; hâmulos 12-13 por asa.

Pilosidade predominante preta. Branca na parte inferior da fronte acima dos alvéolos, na maior parte das paroculares, na supra-clipeal, no clípeo com algumas cerdas pretas misturadas, no labro e mandíbulas e principalmente na porção anterior das genas; em todo lado ventral do tórax e parte inferior dos mesepisternos, nas coxas e nos trocanteres. As cerdas brancas do lado ventral do tórax bastante longas. Cerdas muito curtas esbranquiçadas, denso-plumosas ao redor dos lobos pronotais, ao longo do bordo posterior do pronoto, acompanhando os rebordos laterais do mesoscuto e a sutura transcutal (escuto-escutelar), desde as axilas até a base das asas por sobre a cresta axilar. Fulvo-amarelenta na metade distal das tíbias posteriores e metabasitarsos e formando uma mancha alongada na face ântero-externa das tíbias médias. T1-4 glabros no disco e para os lados, porém nos lados de T4 e em T5-6 com cerdas longas pretas; as franjas de E2-4 brancas, em E5-6 pretas. Nos exemplares jovens com pilosidade curta e plumosa na pontuação posterior do mesoscuto e escutelo, desaparendo nos exemplares mais voados. Pontuação na fronte fina $(20-30 \mu)$, moderadamente densa e os intervalos lisos, um pouco irregular na sua distribuição (1-2dp); semelhante nas paroculares superiores, um pouco mais densa nas inferiores; no clípeo mais grossa, relativamente numerosa com os intervalos lisos (2-4dp), menos densa no terço apical médio; na supraclipeal mais esparsa que no clípeo, adensando-se em direção aos alvéolos; muito densa no vértice, sem grandes áreas lisas entre os ocelos e as órbitas; nas genas relativamente densa; no labro bastante densa, os intervalos em parte careniformes entremeados com alguns um pouco maiores que os pontos no disco. No mesoscuto a pontuação bastante densa 
ao longo do sulco médio deprimido, alargando-se essas áreas pontuadas para a frente e para trás, deixando uma área mais lisa a cada lado [até $4 \mathrm{dp}$ ] diminuindo [até $2 \mathrm{dp}$ ] nos cantos anteriores; alguns micro-pontos esparsos nessas áreas lisas; no escutelo densa como na parte posterior do mesoscuto, com vaga linha média mais lisa; no metanoto mais fina no disco e um pouco engrossada para os lados; nos mesepisternos bastante esparsa (4-5dp) na depressão atrás da dobra anterior e para baixo, um pouco mais densa e os intervalos reticulados em linha média ântero- posterior; nos metepisternos moderadamente densa em cima, mais esparsa em baixo e com os intervalos reticulados. Propódeo com toda área basal mate, reticulada, com alguns pontos grossos cerdígeros esparsos e irregularmente distribuidos; nos flancos bastante densa e os intervalos reticulados, com uma área bastante grande micro-reticulada brilhante entre a área basal e os flancos. T1-3 com alguns pontos curto-pilígeros, para o disco, quase nulos nas depressões marginais, com micro-canaliculação transversal, a margem um pouco sinuada e desbotada; em T4 um pouco mais evidente no meio e bem desenvolvida atrás; em T5-6 numerosa.

Olhos pouco mais de duas vezes sua largura, o dobro das genas de perfil [230:110:50]; face estreitada para baixo, interorbital máxima menor que o comprimento do olho [190:195:145]; malar quase linear [4]; clípeo e supraclipeal moderadamente abaulados, clípeo com estreita depressão apical separada por pontos anastomosados em sulco e o declive para a depressão em arco com a área bastante pontuada, os cantos inferiores levemente rebordados [85:128:145]; subantenal 1,3 o diâmetro alveolar [40]; interalveolar duas vezes a alveolorbital ou o diâmetro do alvéolo [60:30:85:d30]; sulco frontal iniciado por um ponto alongado e pouco separado do fino sulco até o ocelo medio, aí deprimido e o sulco contornando sua metade anterior; interocelar 1,2 a ocelorbital, duas vezes o diâmetro do ocelo [50:42:d25]. Labro 1,62 mais largo que longo. Escapo subcilíndrico, três vezes seu diâmetro [66:d22], bem mais curto que a distância alveolocelar, [P+F 320], ligeiramente mais longo que os dois flagelômeros basais juntos, pouco mais que $1 / 5$ do comprimento do flagelo e pedicelo juntos; flagelômero basal quase o dobro do segundo, este mais curto e o terceiro um pouco mais longo que seu diâmetro [42:22:26:d25]. Pronoto anteriormente um pouco grosso-rebordado; mesoscuto com sulco médio completo e as parápsides mais fracas que os notaulos, estes limitando a área denso-pontuada; mesepisternos com a dobra anterior grosso-careniforme em cima e realçada atrás pela depressão lateral; as placas basitibiais pequenas, lisas, rebordadas. Margem do segundo tergo apenas indicada, no terceiro evidente.

Holótipo fêmea. BrasIL, Rondônia: Ouro Preto do Oeste, 17-27-VIII-1987, Claudionor Elias leg. e mais seis parátipos com os mesmos dados do Holótipo. Coletadas durante a execução do projeto "Polo Noroeste", na Coleção Pe. J.S. Moure (DZUP).

À primeira vista assemelha-se à $T$. amplitarsis pelo tamanho avantajado, aspecto robusto e a grande escopa tíbio-tarsal amarelo-fulvo-pilosa. Basta reparar na pontuação e sulco mesonotais, pontuação na área basal do propódeo para separar essas duas espécies. 
Tetrapedia amplitarsis foi obtida de ninhos artificiais na Fazenda Santa Carlota, Cajurú, São Paulo, Brasil, pelo Prof. Carlos Garófalo e colaboradores, da Universidade de São Paulo, campus de Ribeirão Preto, permitindo assim uma interpretação segura para esta espécie com a qual a havia confundido inicialmente, e por isso dei-lhe o nome específico: $T$. imitatrix.

\section{Tetrapedia melampoda sp.n.}

Fêmea de porte médio: comprimento total aproximado $7,25 \mathrm{~mm}$, da asa anterior 6,42 mm; largura da cabeça 2,55 e do segundo tergo 2,40 $\mathrm{mm}$.

Preta, sem desenhos amarelos. Antenas em parte avermelhadas na base e no ápice do escapo, o pedicelo e flagelômero basal, o flagelo ferrugíneo inferiormente; fêmures castanho-escuros, tíbias posteriores e metabasitarsos ferrugíneos. Tégulas pretas e na área lisa mais para o castanho escuro; asas um pouco escurecidas, principalmente na célula radial; estigma e $\mathrm{R} 1$ amarelos, o restante da venação mélea; hâmulos 10 por asa.

Pilosidade cerdosa preta. Branca nas paroculares inferiores à altura da fóvea tentorial, nos lados do clípeo, na porção proximal das genas; misturada com cerdas pretas no labro. Amarelas duas ou três cerdas no ápice das tíbias posteriores e as cerdas anteriores dos matabasitarsos. Franjas de E1-4 pálidas com algumas com algumas cerdas pretas misturadas, em E5-6 pretas. As cerdas formando um tufo denso a cada lado do escutelo, sobressaindo algumas cerdas longas [até 700 $\mu$ ].

Pontuação cerdígera pouco densa [2-3dp] na fronte, os intervalos lisos, deixando pequenas áreas lisas anteocelares; nas paroculares tão densa como na fronte; no clípeo um pouco mais grossa aos lados, bastante mais esparsa no disco, e no disco da supraclipeal ainda mais esparsa, reduzida a três ou quatro pontos; mais densa nas genas; no vértice mais densa e mais fina, porém quase nula entre os ocelos. No mesoscuto moderadamente densa, um pouco mais para a depressão média, nos cantos anteriores, aos lados e no bordo posterior, com uma pequena área mais lisa [3-5dp], alongada, a cada lado no terço anterior mais próxima ao sulco médio; aos lados entre as parápsides e o bordo alar com alguns intervalos lisos relativamente grandes [2-3dp]; no escutelo muito densa na região dos tufos cerdosos deixando estreita margem lisa anterior e posterior ligadas por uma linha média lisa um tanto obsoleta; no metanoto mais densa que na fronte; nos mesepisternos a depressão atrás de dobra anterior muito forte e careniforme com grande área lisa ântero-inferior e o restante esparsamente pontuado, os intervalos lisos [2-3dp], mais densa na região subalar; nos metepisternos densa em cima e quase nula baixo do espiráculo. Área basal do propódeo relativamente brilhante, com o reticulado muito superficial e algumas séries de pontos em 2-4 linhas transversas irregulares mais próximas à base, para baixo alguns poucos esparsos; nos flancos a reticulação mais forte e os pontos mais densos. Em T1-4 nula nas depressões marginais micro- transverso-canaliculadas superficialmente; base de T1 micro- pontilhado-pilosa no disco; em T2-4 com pequeníssimos pontos cerdígeros, as cerdinhas curtas, mais desenvolvidas apenas nas extremidades laterais; em T5-6 mais densa e aos lados da placa pigidial mais grossa e mais curta. 
Olhos pouco mais de duas vezes mais longos que largos, as genas quase a metade dessa largura [175:80:37]; face alongada, estreitada para baixo com a interorbital máxima bastante mais curta que o comprimento do olho [138:152:110]; malar linear [3]. Clípeo moderdamente abaulado, 1,7 vezes mais largo que longo, seu comprimento cerca de 5/9 da distância ao ocelo médio [62:105:110], a depressão marginal truncada; supraclipeal pouco abaulada; subantenal 1,6 vezes mais longa que o diâmetro do alvéolo [32]; interalveolar 2,3 vezes o diâmetro do alvéolo, alveolorbital apenas excedendo esse diâmetro [46:26: 70:d20]; sulco frontal fino e muito superficial; interocelar ligeiramente maior que a ocelorbital, cerca de 1,73 o diâmetro do ocelo médio [38:36:d22]. Labro 1,5 mais largo que longo [55:85], um pouco deprimido ao longo do meio, emarginado no ápice, bastante densamente pontuado. Escapo quase três vezes mais longo que seu diâmetro [52:18], mais longo que os dois primeiros flagelômeros juntos [P+F 220]; flagelômero basal obcônico quase tão longo como os dois seguintes juntos, o segundo mais curto que seu diâmetro, o terceiro e quarto subiguais, um pouco mais longos que o diâmetro do flagelo [32:15:20:20:d18]. No mesepisterno a dobra anterior em carena muito forte de bordo agudo. Holótipo fêmea. BRASIL, Maranhão: Imperatriz, 27-XII-1972, S. Laroca e Rosado Neto leg.; um parátipo do mesmo local coletado por Th. Dobzhansky, 6-VIII-1949 e outro de Maranhão: Carolina, Th. Dobzhansky leg., 30-VII-1949. Uma fêmea de Mato Grosso: Cáceres, 9-11-XI-1984, Claudionor Elias leg., dentro do projeto "Polo Noroeste. Todos na Coleção Pe. J.S. Moure (DZUP).

São muito característicos nesta espécie sua face alongada, a dobra mesepisternal muito forte e em carena aguda, os dois tufos densos de pêlos no escutelo ilhados pelas margens lisas anterior e posterior e separados pela linha média longitudinal, igualmente lisa; as franjas ventrais formadas por uma mistura de pêlos brancos e pretos; a pilosidade amarela das tíbias posteriores reduzida a duas ou três cerdas no ápice das mesmas e apenas ao bordo anterior dos metabasitarsos.

Num dos exemplares coletados pelo Prof. Th. Dobzhansky ao longo do Rio Tocantins, em suas viagens de estudo das Drosófilas brasileiras - o de Carolina há um pouco mais de pilosidade branca na parte inferior da fronte. Também os micro-tufos de cor cremosa aparecem nos cantos do bordo posterior do mesoscuto e em frente a linha média lisa do escutelo. O reticulado na área basal do propódeo é mais apreciável. O estigma amarelo contrasta bastante com o restante da asa. No exemplar de Imperatriz o sulco frontal um pouco mais marcado acima da área supraclipeal. O exemplar de Carolina é menor: comprimento total aproximado 6,25 $\mathrm{mm}$, da asa anterior $6,25 \mathrm{~mm}$; largura da cabeça $2,45 \mathrm{~mm}$ e do segundo tergo 2,10 $\mathrm{mm}$.

Estou considerando como desta espécie um exemplar de Cáceres, Sudoeste de Mato Grosso, bacia do Paraguai. É maior: comprimento $8,92 \mathrm{~mm}$, da asa anterior $6,67 \mathrm{~mm}$; largura da cabeça 2,60 mm e do segundo tergo 2,22. Não difere do tipo na pontuação do mesoscuto, na estrutura dos mesepisternos com a forte dobra careniforme, na configuração dos tufos do escutelo e na presença das duas ou três cerdas na extremidade distal das tíbias posteriores e estigma amarelo. Até no avermelhado das antenas é muito semelhante ao holótipo. 


\section{Tetrapedia spanosticta sp.n.}

Fêmea de tamanho grande: comprimento total aproximado $10,0 \mathrm{~mm}$, da asa anterior $8,75 \mathrm{~mm}$; largura da cabeça 3,12 e do segundo tergo $3,00 \mathrm{~mm}$.

Preta, sem desenhos amarelos. Flagelo acastanhado por baixo a partir do terceiro flagelômero; tíbias posteriores e metabasitarsos castanho-avermelhados. Tégulas pretas; asas muito escuras; estigma muito escuro, venação preta; hâmulos 12 por asa, um pouco esbranquiçados.

Pilosidade cerdosa toda preta. Com alguns pêlos plumosos esbranquiçados na parte inferior da fronte, algumas cerdas brancas curtas nas paroculares inferiores ao nível das fóveas tentoriais, longas aos lados do clípeo, misturadas no labro; nas genas inteiramente pretas. Branca nas coxas e trocanteres dos dois pares posteriores; amarelo-fulva na extremidade distal das tíbias e nos metabasitarsos. Branca nas franjas de E1-3, misturadas com pretas na base de E4 e inteiramente pretas em E5-6. Indícios de flocos formados por pêlos cremosos curto-plumosos, bastante densos contornando os lobos pronotais por trás e acompanhando as crestas axilares.

Pontuação de tamanho moderado [cerca de $35 \mu$ ], bastante densa na fronte, os intervalos lisos (1dp) ou ligeiramente maiores; uma estreita linha média acima da supraclipeal seguida pelo sulco frontal, deixando uma faixa lisa completa entre as órbitas ligando todas as áreas lisas anteocelares com cerca de um ocelo de largura; nas paroculares um pouco mais esparsa; no clípeo e supraclipeal muito esparsa [3-5dp] os intervalos lisos; nas genas mais fina, os intervalos micro-reticulados (2-3dp); no vértice fina e densa. No mesoscuto muito esparsa (3-5dp) em toda a extensão, mesmo ao longo do fino sulco médio e com alguns micropontos intercalados, mais densa ao lados, porém esparsa no bordo posterior; no escutelo um pouco menos esparsa, os intervalos lisos [2-3dp]; no metanoto menos esparsa, os intervalos [1-2dp] fracamente reticulados na região média; nos mesepisternos, atrás da fraquíssima dobra anterior, esparsa, os intervalos micro- reticulados [2-3dp], para baixo maiores [4-6dp], por baixo das asas e atrás mais densa; nos metepisternos, muito estreitos [apenas $20 \mu$ ], inteiramente reticulados, esparsa em cima e quase nula em baixo. Propódeo todo micro-reticulado, na área basal com poucos pontos esparsos separados em dois grupos de 11 pontos cada um a cada lado de um fraco sulco médio estendido até em baixo; nos flancos moderadamente densa, os intervalos [2-3dp] mate-reticulados. T1-4 com largas depressões marginais micro-transverso-reticuladas, sem pontos; toda parte basal dorsal de T1 bastante densamente micro-pontuada-pilosa (os pelinhos muito curtos e finos), com os intervalos superficialmente micro-transverso- canaliculados, em T2-4 esse pontilhado cada vez menos denso e os pelinhos passando a cerdas curtíssimas no T2, mas bem evidentes no T3 e principalmente em T4; T5-6 denso-pontuado-cerdosos. Os esternos também microcanaliculados, os canalículos transversais.

Olhos 2,33 mais longos que largos, mais do dobro das genas de perfil [210:90;40]; malar linear [3]; face estreitada para baixo com a interorbital máxima menor que o comprimento do olho [175:190:150]; clípeo e supraclipeal fracamente abaulados, deprimidos para a sutura espistomal, o clípeo liso ao longo do meio com o bordo apical fortemente rebaixado e pontuado no terço médio, os cantos inferiores ligeiramente deprimidos, 1,7 vezes mais largos que longos e o comprimento cerca 
de 2/3 da distância ao ocelo [85:145:130]; subantenal tão longa como 1,5 do alvéolo [38]; interalveolar 2,4 o alvéolo e a alveolorbital 2/3 da interalveolar [60:40:80:d25]. Sulco frontal muito fino começando entre os alvéolos e chegando ao ocelo em forma de fina depressão; interocelar ligeiramente menor que a ocelorbital, com 1,6 diâmetro do ocelo médio [40:42:d25]. Labro 1,5 mais largo que longo [70:105], moderadamente pontuado, um pouco deprimido ao longo do meio, sinuado apicalmente e com os cantos arredondados. Escapo mais de três vezes seu diâmetro [70:20], um pouco mais longo que os dois flagelômeros basais juntos; flagelômero basal obcônico, duas vezes o segundo; este tão longo como seu diâmetro, terceiro e quarto subiguais e um pouco mais longos que o diâmetro do flagelo [42:20:25:25:d20]. Mesepisternos com a dobra anterior fraca, em aresta grossa.

Holótipo fêmea. BRASIL, Minas Gerais: Itajubá (Serra dos Toledos), 11-XII1955, Pe. Francisco Silverio Pereira leg., na Coleção Pe. J.S. Moure (DZUP).

Lembra $T$. amplitarsis e $T$. imitatrix, porém é única pela pontuação extremamente esparsa no mesoscuto, mesmo ao longo do sulco médio, com intervalos lisos entre três a cinco diâmetros de ponto e alguns pontinhos intercalados; a dobra anterior dos mesepisternos fraca, em aresta grossa, e a depressão mate, micro-reticulada. A escopa fulvo-amarela reduzida ao quarto distal da tíbia e ao metabasitarso.

O nome específico refere-se a pontuação muito escassa do mesoscuto.

\section{Tetrapedia xanthorrhina sp.n.}

Macho, de porte médio. comprimento total aproximado $8,0 \mathrm{~mm}$, da asa anterior $6,6 \mathrm{~mm}$; largura da cabeça $2,5 \mathrm{~mm}$ e do segundo tergo $2,2 \mathrm{~mm}$.

Preta. Com uma faixa amarela premarginal no clípeo, um pouco estreitada para os lados, com o labro e mandíbulas sem manchas. Flagelo inferiormente ocráceo-pálido; pernas castanho-escuras com os 3/7 distais das tíbias posteriores e os basitarsos amarelo-ferrugíneos. Tégulas pardo-escuras; asas fracamente escurecidas (um pouco mais as células média e radial); venação escura, estigma ocráceo; hâmulos 8 por asa.

Pilosidade predominante preta. Branca na área supraclipeal, clípeo e áreas paroculares desde pouco acima da tangente alveolar superior, porém nas genas preta; um pequeno tufo de finas cerdas plumosas nos cantos posteriores do mesoscuto e nos mesepisternos; curta, muito visível em certa luz, na face interna dos fêmures posteriores; as cerdas longas marginais de E3-4 enegrecidas no ápice e voltadas para dentro. Amarelo-fulva na metade distal das tíbias posteriores; a franja posterior dos metabasitarsos nos três quartos basais passando a preta no quarto distal, larga na base e estreitando-se para o ápice [1000->400 $\mu$, o tufo mediano distal da face interna preto (algumas cerdas até $800 \mu$ ) faltando as longas cerdas curto-plumosas, onduladas, no bordo interno da sola. Preta, bastante notável, esparsa, não muito longa no disco de T1-3, em T4 e seguintes mais longa; as franjas de pêlos curtos denso-plumosos na margem de T5-6 fracas, pretas, predominando as cerdas longas intercaladas; em T7 mais curtas, porém bastante numerosas.

Pontuação na fronte fina [25-30 $\mu$, esparsa [até $2 \mathrm{dp}]$, ainda mais para os lados e deixando uma faixa absolutamente lisa ante-ocelar, um pouco inchada; no vértice mais densa e mais fina; nas paroculares mais esparsa que na fronte; no clípeo ainda 
mais esparsa e quase nula no disco da supraclipeal; nas genas mais fina e mais esparsa que na fronte [2-4dp]. No mesoscuto muito densa ao longo da linha média, os intervalos careniformes, no restante mais esparsa [até $2 \mathrm{dp}$ ] deixando uma larga estria lisa [3-5dp] a cada lado; no escutelo mais densa que no mesoscuto, sem linha média lisa e a faixa lisa posterior pouco destacada; no metanoto mais fina e mais densa que no escutelo; na depressão lateral do mesepisterno atrás da dobra bastante esparsa e mais fina que no mesoscuto, ainda mais esparsa para baixo [4-6dp]. No propódeo toda a área basal pontuada (os pontos com cerdas plumosas finas relativamente longas, mais curtas para a base), os intervalos lisos, cerca de 2-3dp; nos flancos, entre a base e os espiráculos, mais esparsa e os intervalos lisos. Nos tergos e esternos apenas a pontução pilígera, moderadamente densa no disco dos quatro primeiros, quase nula aos lados.

Olho pouco mais de duas vezes sua largura; genas mais estreitas que a metade da largura do olho [170:80:32]; malar linear [3]; face relativamente estreita, órbitas mais convergentes para baixo, interorbital máxima cerca de $5 / 6$ do comprimento do olho [125:140:108]; clípeo tão longo como 3/5 da sua largura, ou 4/7 de sua distância ao ocelo médio [60:100:105], moderadamente abaulado, praticamente sem a estreita área deprimida marginal; supraclipeal pouco abaulada; subantenais tão longas como $1,5 \mathrm{~d}$ de alvéolo [30]; interalveolar 2d, alveolorbital 1,3d [42:26:65:d20]; sulco frontal fino, evidente apenas a cima da metade da fronte; interocelar 1,5d, ocelorbital mais estreita (1,25d)[36:29:d24]. Labro duas vezes mais largo que longo, deprimido no meio, com o bordo anterior sinuado em semicírculo e arredondado aos lados. Escapo 3,3d [50:d15], mais longo que os dois primeiros flaglômeros juntos, apenas $1 / 5$ do comprimento do pedicelo e flagelo juntos [P+F 240]; flagelômero basal duas vezes o segundo, o terceiro e quarto subiguais, superando ligeiramente o próprio diâmetro [33:16:20:20:d18]. Mesepisterno com dobra anterior fortemente careniforme. Armadura das coxas e trocanteres posteriores muito fraca, reduzida a pequenas saliências curto-tuberculiformes de ápice liso; fêmures moderadamente grossos [180:80]; tíbias clavadas, mais longas que os fêmures [220: 80]; metabasitarsos longos e relativamente estreitos [150: 40: 40:40], bordo posterior um pouco mais curvo na base; sola quase plana, rebordada, sem dentes ou expansões, distalmente um pouco alargada em parábola, torcida para dentro. Tergos levemente sinuados, desbotados na margem; T7 bastante pontuado-piloso com a margem posterior sinuada em semicírculo.

Holótipo macho. BRAsIL, Mato Grosso: Vila Bela, 3-VI-1986, S. Marcolino leg., na Coleção Pe. J.S. Moure (DZUP). Vila Bela fica na Chapada dos Parecís que separa as Bacias do Paraná e do Amazonas.

Pelo seu aspecto alongado, pontuação no propódeo e desenho clipeal, esta espécie lembra $T$. pyramidalis Friese, 1899. Esta última difere pela falta de dobra mesepisternal, pela franja dos metabasitarsos preta, igualmente densa e uniforme por trás e pelos lados deixando glabra apenas a sola inerme, em plano contínuo alargado progressivamente da base para o ápice espatulado, pelo sétimo tergo subtruncado, com leve carena média e largamente liso. Estigma e R1 não são tão intensamente amarelados como em $T$. pyramidalis, cuja fêmea foi descrita por SCHROTTKY (1913) como T. xanthostigma, do extremo oeste paranaense: Porto Majoli, Guaíra, Paraná, Brasil. 


\section{Tetrapedia nigropilosa sp.n.}

Macho de porte relativamente grande: comprimento total aproximado 9,58 $\mathrm{mm}$, da asa anterior 7,5 $\mathrm{mm}$; largura da cabeça $2,92 \mathrm{~mm}$ e do segundo tergo 2,0 $\mathrm{mm}$.

Preta, sem desenhos amarelos. Antenas manchadas de castanho-avermelhado; 3/8 distais dos fêmures posteriores castanho-ferrugíneos; metabasitarsos castanho-amarelados, mais escurecidos em direção ao bordo da sola. Tégulas castanhoescuras, quase pretas; asas moderadamente fuscas; estigma um pouco amarelado e venação mélea; hâmulos 10 por asa.

Pilosidade predominante preta. Branco-plumosa na base da fronte, mais numerosa nas áreas paroculares inferiores, e cerdas no clípeo e supraclipeal; curto-plumosa nas genas junto às órbitas e em E3-4 formando tomento branco em arco incluindo arco menor escuro-piloso e na margem com cerdas longas cremosas, de ponta escura, voltadas para dentro. No quarto distal dos fêmures posteriores um tufo de pêlos finos densamente plumosos de cor cremosa entremeados de cerdas amarelas sobressaindo de um terço ao tufo; nos metabasitarsos a franja inteiramente preta de pêlos finos distalmente plumosos, mais larga na base e estreitando-se para o ápice [ $800->400 \mu$ ] e com cerdas sobressaindo $120 \mu$ além da franja, com uma série de cerdas longas pretas, um pouco onduladas, curto-plumosas implantadas no bordo interno da sola [até $1000 \mu$ ]. Tufos densos marginais entremeados por cerdas pretas longas salientes em T4-6, em T6 sem deixar faixa glabra basal.

Pontuação na fronte moderada $[30 \mu]$, os intervalos lisos cerca de $2 \mathrm{dp}$, mais fina nas paroculares; muito esparsa no clípeo e supraclipeal, grandes áreas lisas [até $10 \mathrm{dp}]$, um pequeno sulco ou degrau pré-apical no terço médio do clípeo com uma série transversal de pontos com cerdas; pouco densa nas genas; mais fina e mais densa no vértice atrás dos ocelos, aos lados bastante esparsa e ainda mais nas áreas ante-ocelares porém sempre intercaladas com alguns pontos finos, a média deprimida pelo sulco frontal e sem pontos, estreita, sem formar faixa lisa transversal de órbita a órbita. No mesoscuto moderadamente densa, mais [1dp] ao longo do meio, aos lados e atrás, deixando a cada lado do disco uma área lisa [2-3dp] com alguns micropontos; no escutelo quase igual à do mesoscuto, porém mais densa, os intervalos lisos menos de $1 \mathrm{dp}$, a faixa lisa posterior obsoleta uma pouco alargada para os lados, sem linha média; no metanoto mais fina e igualmente densa; na depressão lateral dos mesepisternos um pouco mais grossa que no mesoscuto $[40 \mu]$, mais densa acima [1/2dp] e mais esparsa em baixo [2-4 dp] e principalmente para trás, na face mesepisternal atrás da dobra anterior semelhante à do metanoto; nos metepisternos tão grossa e mais densa em cima, quase nula abaixo da fóvea. Propódeo com a área basal mate-reticulada, com poucos pontos esparsos (3-5dp) em V aberto imperfeito; pontuação densa para o lado interno do espiráculo acompanhando os limites da área, muito esparsa para baixo, muito forte e densa entre o espiráculo e o metepisterno. T1-3 extremamente lisos e brilhantes, com pouquíssimos pontos pilígeros; T4-6 cada vez mais densa, com faixa lisa basal em T4-5, em T7 bastante densa aos lados da carena média.

Olhos pouco mais longos que duas vezes sua largura; genas de perfil menos da metade da largura do olho [195:95:40]; órbitas internas pouco sinuadas, conver- 
gentes para baixo, a distância máxima interorbital bem menor que o comprimento do olho [150:175:120]. Clípeo pouco abaulado, com a depressão apical pouco definida, porém declive em arco desde a metade e toda essa área quase sem pontos, lisa e brilhante, 1,2 vezes mais largo que longo, seu comprimento cerca de 7/8 da sua distância ao ocelo [90:115:110]; malar linear [3]; subantenais 1,4 vezes o alvéolo [35]; interalveolar mais de $2 \mathrm{~d}$ de alvéolo, alveolorbital 1,3 [55:32:70:d25]; sulco frontal evidente desde entre os alvéolos; interocelar igual à ocelorbital, cerca de 1,5d [38:38:d25]. Labro tão longo como 5/9 da sua largura, bastante liso e plano, truncado apicalmente com pequeno chanfro médio, os cantos arredondados. Escapo três vezes seu diâmetro [60:d20], mais curto que os três primeiros flagelômeros juntos; flagelômero basal 1,6d, os três seguintes iguais entre si e ao próprio diâmetro [32:20:20:20:d20]. Escutelo sem tufo a cada lado; mesepisterno com a dobra anterior forte, careniforme; coxas posteriores fracamente armadas, trocanteres em ângulo mais pronunciado, parecendo um espinho em vista posterior; metabasitarso quase reto no bordo posterior e fracamente côncavo no interior, um pouco mais dilatado para o ápice [200:50:70]; sola de lados subparalelos, um pouco dilatadoarredondada no ápice e o plano um pouco torcido-inclinado para trás a partir do dente subtrapezóide similar ao de $T$. diversipes. Aresta anterior do mesepisterno forte e relativamente aguda com a depressão posterior marcada e com forte pontuação.

Holótipo macho. PARAGUAI: Guayrá (Colônia Carlos Pfannel), 20-X-1950, F.H. Schade leg., na Coleção Pe. J.S. Moure (DZUP). Falta o pedicelo e flagelo da antena esquerda. Os basitarsos tem a mesma configuração que em $T$. diversipes Klug, 1810.

Vi mais de 600 exemplares de $T$. diversipes, porém nada que se aproxime pelo colorido da pilosidade e dos basitarsos posteriores.

Para separar estas duas espécies, além da cor da pilosidade, veja-se a pontuação e pilosidade do abdômen: em $T$. diversipes nos três primeiros tergos há muito mais pontos pilígeros no disco, o mesmo acontecendo no labro. Esses exemplares de T.diversipes vieram principalmente do litoral (Mata Atlântica) desde a Bahia até o Rio Grande do Sul. O basitarso posterior do macho é amareloferrugíneo e tem a franja posterior amarela nos $5 / 8$ basais e preta nos $3 / 8$ distais. Em exemplares de Maracás, Bahia, as franjas estão formadas por pêlos plumosos pretos, mais pálidos para a base; esse mesmo tipo de pêlos ocorre na extremidade distal das tíbias posteriores, porém aqui misturados à pilosidade fina plumosa amarela. Em $T$. diversipes a pontuação na depressão mesepisternal atrás da dobra anterior parece ser um pouco mais fina e mais esparsa.

\section{Tetrapedia pulchella sp.n.}

Macho, de porte médio: comprimento total aproximado $7,9 \mathrm{~mm}$, da asa anterior $6,7 \mathrm{~mm}$; largura da cabeça $2,32 \mathrm{~mm}$ e do segundo tergo $2,1 \mathrm{~mm}$.

Preto; com grande mancha triangular amarela ocupando quase todo clípeo, a cada lado com pequena reentrância preta. Antenas com o pedicelo e flagelo largamente ferrugíneos, os três últimos flagelômeros mais escuros; pernas médias 
e posteriores castanho-escuras, metabasitarso muito escuro, quase preto, com o dente basal pardo-claro. Tégulas castanho-escuras; asas lavadas de ocráceo-amarelado; estigma amarelo, a venação mélea. Hâmulos 9 por asa.

Pilosidade preta e branca com distribuição característica, adornando muito a espécie. Preta na parte superior da fronte, vértice, genas; misturada com alguns pêlos brancos no mesoscuto, escutelo e metanoto; na metade superior dos mesepisternos; em grande parte das pernas anteriores e médias; nos tergos. Pálido-ocrácea na face ântero-externa das tíbias e basitarsos médios. Branca na metade inferior da face, com algumas cerdas pretas no clípeo, área supraclipeal e paroculares; formando uma área de pêlos brancos finos longo-plumosos na parte inferior da fronte e uma mancha longitudinal de pêlos denso-plumosos amarelo-pálidos afastados das órbitas nas paroculres superiores; no propódeo, na metade inferior e todo lado ventral do tórax e do abdômen; as franjas de tufos plumosos dos últimos tergos pardo- cinzentas; as longas cerdas marginais dos esternos terceiro e quarto com pontas pretas curvadas para o centro; nas coxas, trocanteres e fêmures posteriores; estes com a face posterior preto-pilosa nos três quartos basais e amarelenta no quarto distal. Franja dos metabasitarsos preta. Cerdas longas $[500 \mu]$ do escutelo pretas, imperfeitamente distribuidas em dois tufos (o exemplar um pouco danificado), com alguns pêlos brancos longo-plumosos aos lados e nos cantos posteriores do mesoscuto. No tergo basal relativamente escassa, nos dois seguintes mais numerosa, preta no disco, esbranquiçada mais longa e esparsa para a margem; no quarto mais densa; no quinto e sexto formando franja curto-denso-plumosa, pardo-cinzenta; no sétimo mais curta e mais esparsa.

Pontuação na fronte fina $(20-25 \mu)$ com intervalos lisos de 2-3dp, mais esparsa nas paroculares, deixando faixa anteocelar lisa transversal de órbita a órbita; mais densa e fina no vértice atrás dos ocelos; no clípeo bastante esparsa [3-5dp]; com poucos pontos no disco da supraclipeal; moderadamente densa nas genas [2dp]. No mesoscuto os pontos um pouco maiores $[25-30 \mu]$, largamente esparsos no disco, sem formar linha média com pontos mais adensados, os intervalos lisos [3-5dp] com alguns micro-pontos intercalados, bastante adensada [1/2dp] para os lados e para os cantos posteriores; no escutelo de igual tamanho porém mais densa, intervalos quase como os pontos, deixando uma linha média lisa, sem faixa lisa posterior; no metanoto um pouco mais fina, os intervalos maiores que os pontos; na face lateral dos mesepisternos com pontuação bastante forte e densa (difícil de observar pela pilosidade plumosa bastante densa e longa), os intervalos careniformes em cima, maiores que os pontos em baixo, com alguns pontos até $40 \mu$ e intervalos lisos mais esparsos [2-dp] em baixo; metepisternos pontuados acima do espiráculo. Propódeo um pouco inchado e abaulado, na área basal com pontos como no escutelo, muito esparsos, os intervalos lisos [2-4dp] ainda mais esparsos para a base da área, os intervalos micro-reticulados aos lados e por baixo da área basal sem pontos, nos flancos moderada $[30 \mu]$ os intervalos reticulados. Em T1 com pontos pilíferos finos esparsos, os intervalos lisos [3-4dp], em T2-3 mais numerosa, discal; em T4 bastante mais desenvolvida; em T5-6 com franjas distais de pêlos curto-denso-plumosos entremeados de cerdas mais longas; T7 esparso-pontuado- piloso.

Olho 2,22 sua largura, mais de duas vezes a largura da gena [160:72:34]; face estreita e bastante estreitada para baixo, a interorbital máxima 7/8 do compri- 
mento do olho [130:140:100]; malar linear [3]; clípeo com barra translúcida marginal, 1,5 mais largo que longo, seu comprimento pouco menos de $2 / 3$ da sua distância ao ocelo $[65 ; 98 ; 100]$; subantenal quase duas vezes o diâmetro do alvéolo [30]; a supraclipeal uniformemente abaulada; a interalveolar $2 \mathrm{~d}$ alvéolo, alveolorbital $3 / 4$ da interalveolar [40:30:65:d18]; sulco frontal quase nulo representado apenas pela depressão na área ante-ocelar; interocelar maior que a ocelorbital, 1,5d ocelo [34:30:d22]. Labro não examinado por estar coberto pela peças bucais presas entre as mandíbulas. Escapo curto 2,55 seu diâmetro [46:d18], pouco mais de 1/5 do pedicelo e flagelo juntos $[\mathrm{P}+\mathrm{F} 220]$ e mais longo que os dois primeiros flagelômeros; flagelômero basal sem chegar ao dobro do segundo, terceiro, quarto e respetivos diâmetros subiguais [26:14:16:17:d16]. Mesepisterno com a passagem da face lateral para a anterior arredondada, sem formar dobra careniforme porém atrás com fraca área deprimida. Pernas posteriores com as coxas armadas por forte espinho apical, os trocanteres projetados além da articulação femoral por uma lâmina perpendicular de ápice projetado-arredondado; fêmures engrossados (155:80), as tíbias clavadas mais longas e tão grossas como os fêmures (200:80). Metabasitaros 7/10 do comprimento da tíbia, pouco curvos, estreitados no meio (140:40:30: 40); sola arredondado-espatulada (130:30:20:43) com um forte dente sub-retangular, mais alto que largo (20:16), próximo à base, perpendicular ao bordo interno; franja posterior atenuada para o ápice $(600: 300 \mu)$; no bordo externo da sola com longas cerdas curto-plumosas pálidas $(600 \mu)$, onduladas irregularmente. Último tergo subtruncado, imperceptivelmente sinuado.

Holótipo macho. Argentina, Tucumán: San Pedro Colalao, II-1949, P. Arnau leg., na Coleção Pe. J.S. Moure (DZUP).

É uma Tetrapedia das mais "enfeitadas" (pulchella) que conheço. Chama a atenção pela abundância e graciosa distribuição dos pêlos brancos, pela grande mancha amarela triangular no clípeo semelhante à de $T$. clypeata Friese, 1899, espécie muito mais robusta. A lâmina arredondada projetada além da articulação entre o trocanter e o fêmur posterior com a base inteiramente desarmada é peculiar a esta espécie e faz bom contraste com o grande espinho coxal. O dente sub-retangular basal do bordo posterior da sola basitarsal lembra um pouco o de $T$. diversipes, de contorno diferente: trapezoidal e um pouco mais afastado da base. Dobra mesepisternal arredondada.

\section{Tetrapedia alfkeni Cockerell, 1914}

Tetrapedia alfkeni Cockerell, 1914: 321.

Recebi há muitos anos do saudoso Dr. A. da Costa Lima uma fêmea de $T$. alfkeni Cockerell, 1914, que lhe enviara o Prof. Francisco Campos, de Guayaquil, Ecuador, procedente de Balzar, III-1948. Trata-se de uma espécie parecida à $T$. melampoda, que aqui se descreve e por isso dou abaixo alguns esclarecimentos sobre T. alfkeni.

É notável por ter as pernas posteriores inteiramente pretas, com cerdas brancas longas no bordo antero-interno das tíbias e entre as cerdas pretas com tufos de pêlos finos plumosos murinos na parte distal das tíbias e posterior dos basitarsos; as fimbrias dos esternos inteiramente pretas. Pilosidade branca nos $2 / 3$ inferiores da 
face e muito notável nas genas. Pontuação do mesoscuto densa, passando a mais esparsa (2dp) aos lados e na frente das parápsides. Dobra mesepisternal anterior fraca, não carenada, formando atrás depressão fraca, de fundo micro-reticulado, os pontos moderadamente grossos $(40 \mu)$ em baixo separados por $2-2,5 \mathrm{dp}$, para cima mais densa; área basal do propódeo toda mate-reticulada, com pontuação bastante densa sem linha ou sulco médio. Tergos com as margens desbotadas, os quatro primeiros quase sem pontos, micro-canaliculados transversalmente.

Comprimento total aproximado $8,3 \mathrm{~mm}$, da asa anterior $7,25 \mathrm{~mm}$; largura da cabeça $2,72 \mathrm{~mm}$, do segundo tergo 2,5 mm. Distância interocelar 38, ocelorbital 30 e diâmetro do ocelo médio 22 .

Tive em mãos os síntipos de T. alfkeni: um no American Museum of Natural History (13-V-1957) e outro no Museum of Comparative Zoology, Harvard (tipo $\mathrm{n}^{\circ}$ 16396, em 3-VI-1957).

\section{Tetrapedia basalis Smith, 1879}

Tetrapedia basalis Smith, 1879: 129.

Transcrevo abaixo a descrição de Smith e minhas notas sobre o tipo conservado no Natural History Museum em Londres.

Fêmea. 4 1/2 linhas (cerca de 9,5 mm). Preta, o abdômen muito liso e brilhante. Um pouco de pubescência branca aos lados da face e tambem na inserção das antenas; o clípeo com poucos pontos distantes, a sua margem anterior fracamente emarginada; as pontas das mandíbulas pálido-testáceas; o flagelo das antenas, menos os três segmentos basais, obscuramente fulvos por baixo. O mesotórax brilhante e pontuado; as asas, da base ao estigma, pardo-escuras, a porção apical branco-leitosa; as pernas com pilosidade preta, a das tíbias posteriores e do primeiro artículo dos tarsos muito densa e longa. $\mathrm{O}$ abdômen pubescente no ápice; por baixo, o terceiro e o quarto segmentos com pilosidade fulvo-pálida e a dos segmentos apicais preta.

Distribuição geográfica. Brasil, Fonte Boa, no Oeste do Amazonas, pouco antes de Tefé, muito provavelmente procedente das coletas feitas por Bates.

As minhas notas sobre o tipo fêmea, 17B590, Fonte Boa 70/16, em 21 de setembro de 1957, dizem o seguinte: É uma Tetrapedia (Lagobata? pois há escamas para os lados do mesonoto e mais no propódeo (área basal) e principalmente no metanoto e escutelo\} destes surgindo pêlos longos. Cor das asas muito típica, fusca até o pterostigma e depois pálido-ferrugínea sendo a venação da mesma cor da membrana alar.

Pilosidade longa pálida no labro (no bordo fusco-piloso), clípeo, supraclipeal, E1-3, lado ventral do tórax, coxas e fêmures III e parte anterior das tíbias III; nos T4-6 e E4-6 preta. Notar que as longas cerdas dos esternitos são ligeiramente claviformes para a ponta! Há pilosidade plumosa branca baixa nas paroculares, na fronte e nas genas.

Pontuação escassa no clípeo, quase nula na supraclipeal, ocelorbitais absolutamente lisas; forte e com alguns pontinhos intercalares no mesoscuto. Tergitos micro-chagrinados e com poucos pontos; mesepisternos e flancos do propódeo bem mais fracos e mais finos que os do mesoscuto. 
Fraca carena ao longo do meio do clípeo.

Comprimento total aproximado $11 \mathrm{~mm}$; da asa $10,8 \mathrm{~mm}$; [largura da] cabeça $3,4 \mathrm{~mm}$ e [do segundo tergo do] abdômen 3,4 mm. Olho [5x]125:85:70; a interalveolar 30:17; [comprimento do] clipeo e [distância] clipocelar 42:70; antena 35:12:20:9:12:13:d14.

A presença de escamas no tórax e propódeo, a configuração dos pêlos nos esternos e a cor da pilosidade separam bem esta espécie das outras que tem asas bicolores.

\section{REFERÊNCIAS BIBLIOGRÁFICAS}

Cockerell, T.D.A. 1914. Bees from Ecuador and Peru. Jour. N.Y. Entomol. Soc. 22: 306-328.

FrIESE, H. 1899. Monographie der Bienengattungen Exomalopsis, Ptilothrix, Melitoma und Tetrapedia. Ann. k.k. naturhist. Hofmuseum 14 (3): 247-304. NASCIMENTO, P.T.R. 1979. Catálogo dos tipos entomológicos do Museu Goeldi: Hymenoptera. Bol. Mus. Paraense Emilio Goeldi, Zoologia, 98: 1-18.

SCHROTTKY, C. 1913. La distribución geográfica de los himenópteros argentinos. An. Soc. Cient. Arg. 75: 115-144; 180-286.

SMITH, F. 1879. Descriptions of new species of Hymenoptera in the collection of the British Museum. London, XXI+240. 